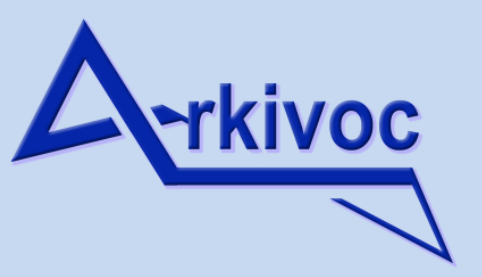

Free to Authors and Readers
A Platinum Open Access Journal for Organic Chemistry
Tribute

DOAJ Seal

Arkivoc 2021, part v, 1-6

\title{
Professor Peter A. Jacobi
}

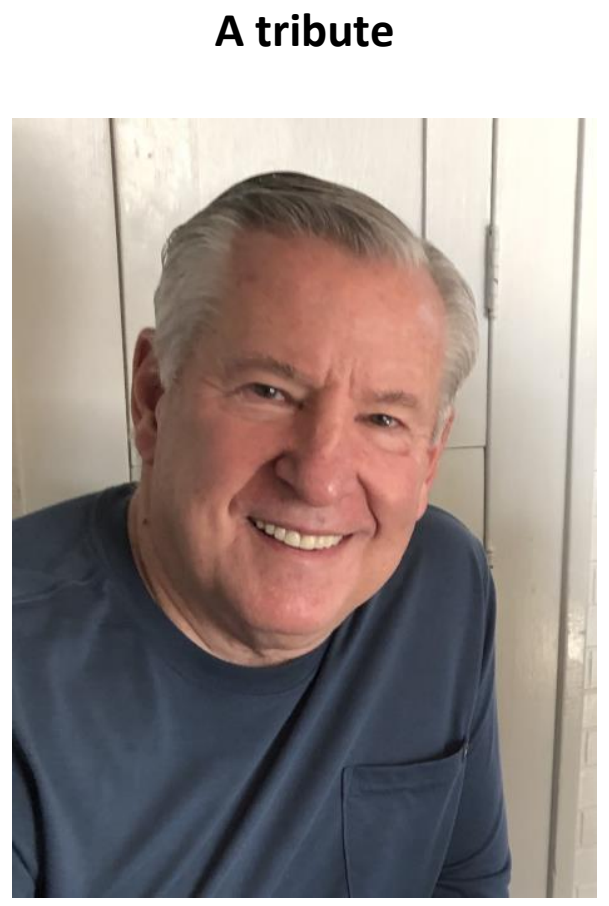

This special issue of Arkivoc is dedicated to Professor Peter A. Jacobi on the occasion of his retirement

Published on line 06-04-2020 
Peter A. Jacobi was born and raised in Bethayres, Pennsylvania, at that time a bucolic small town on the northeast side of Philadelphia, as the youngest of the three sons of Edward A. and Sophie B. Jacobi. He attended Lower Moreland High School, graduating in 1963. A relatively indifferent student throughout most of his early schooling, his parents thought (hoped?) that Peter might eventually take over the family printing business, a small operation located at the corner of 4th and Green Streets, in what was then a less desirable neighborhood of Philly. He had not given serious thought to attending college until 1960 when a transformative event took place in Squaw Valley, California - the Winter Olympics. The events were televised and signaled the beginning Peter's lifelong interest in winter sports. In short order, he was embarking on regular ski trips to Vermont. It was on one of these trips that a fellow enthusiast, Ray Kressler and a close friend of Peter's brother John, suggested that Peter might consider attending college in New England. That input, together with the inspiration of several excellent high school teachers in chemistry (Charles Jessup and Richard Person) was all it took to seal the deal and send Peter off to college.

Peter Jacobi received his B.S. degree in Chemistry in 1967 from the University of New Hampshire under the tutelage of Gloria Lyle, whereupon he journeyed to Princeton University where he received his Ph.D. in Organic Chemistry in 1973 under the direction of Edward (Ted) Taylor. After two years at Harvard University as a postdoctoral fellow in the laboratories of Nobel laureate R. B. Woodward, he joined the Department of Chemistry at Wesleyan University as an Assistant Professor where he was mentored by Dr. Max Tishler, a recent transplant from Merck \& Co. and a close personal friend of Woodward. He rose rapidly through the ranks, and in 1993 Peter was named the John Wesley Beach Professor of Chemistry. In the fall of 1997 he moved from Wesleyan University to Dartmouth College and was appointed the New Hampshire Professor of Chemistry in 2004, a position he held until 2013.

In recognition of his many accomplishments in research and education, Peter Jacobi has been the recipient of a number of awards. For example, he received the American Cyanamid Company Award for "Advancement of the Art and Science of Synthesis" (1985), the Connecticut Valley ACS Award for "Outstanding Contributions to Chemistry" (1988), and the Caleb T. Winchester Award for "Excellence as a Scholar-Teacher" (1996). In 2010 he was elected as a Fellow of the American Chemical Society, and in 2019 he was awarded the Robert A. Fish 1918 Memorial Prize, in recognition of outstanding contributions to undergraduate teaching at Dartmouth. He is the author of nearly 100 peer-reviewed publications in the general area of natural products chemistry, as well as the text "Introductory Heterocyclic Chemistry".

Peter lives in Hanover, New Hampshire, USA, with his wife Lee Ann. His daughter Tracey lives close by in Lyme, New Hampshire, and daughter Kristi lives in Norwood, Massachusetts. Together, Lee Ann and Peter share 12 grandchildren. His hobbies include a strong interest in many outdoor activities, and in retirement he hopes to upgrade his skills in skiing and piano.

The research interests of Peter Jacobi and his many students and postdoctoral associates over the years have been broadly based, but were focused in three important areas of organic chemistry: (1) mechanistic theory, providing a detailed analysis of how reactions occur; (2) synthetic methodology, developing new reactions and procedures for synthesizing organic molecules; and (3) the synthesis of complex molecules of either natural or unnatural origin. This last area is often the most challenging and serves as a measure of our understanding of the science. Over the course of Peter's productive career his research group completed the total syntheses of more than thirty natural products, many of which have interesting biological activity. Representative examples from the Wesleyan years include saxitoxin (1), the paralytic agent of the so-called "red tide" that is used to study certain nerve disorders; gnididione (2), a member of the guaiane family of furanosesquiterpenes; juncusol (3), an antimicrobial-cytotoxic agent with an unusual dihydrophenanthrene skeleton; and a wide variety of oxygenated sesquiterpenes and alkaloids, including stemoamide (4). 




Saxitoxin (1)

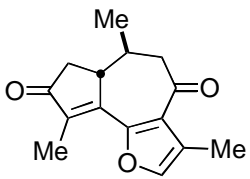

Gnididione (2)

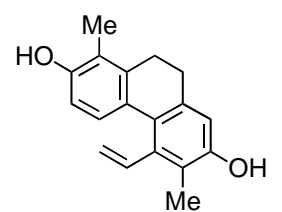

Juncusol (3)



Stemoamide (4)

At Dartmouth his research group devoted considerable effort to exploring enantioselective syntheses of pentynoic acids of the general structure 5, because they are versatile intermediates that were used to prepare biologically important lactones such as nephrosteranic acid (6), carbapenem antibiotics including thienamycin (7), and members of the hydroporphyrin (8) class of macrocyclic tetrapyrroles. Species of type 8, including numerous chlorins and bacteriochlorins, were synthesized and studied as chromophores in tumor photodynamic therapy (PDT), wherein malignant tissue is eradicated by photostimulated production of singlet oxygen.





Thienamycin (7)

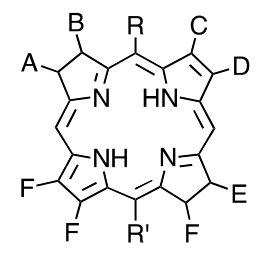

Hydroporphyrin (8)

A highlight of the pentynoic acid chemistry involved the first enantioselective synthesis of phytochrome (9), the photoreceptor that controls photomorphogenesis in higher plants. It is in this critical biological process that light transmits vital information to the genetic apparatus of a plant cell (transduction). ${ }^{13} \mathrm{C}$-labeled derivatives of $\mathbf{9}$ were prepared to study the mechanism of photomorphogenesis in collaboration with groups at UCal Davis and Berkeley. In other tetrapyrrole projects, novel chemistry was developed toward the synthesis of tolyporphin A (10) and cobyric acid (11). Tolyporphin A (10) is a member of the bacteriochlorin class of tetrapyrroles that has promising activity as an agent for reversing multi-drug resistance (MDR), whereas cobyric acid (11) comprises the corrin core of vitamin $B_{12}$.

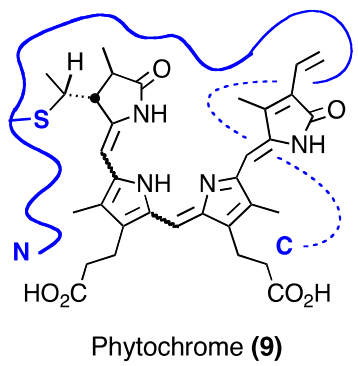

Phytochrome (9)

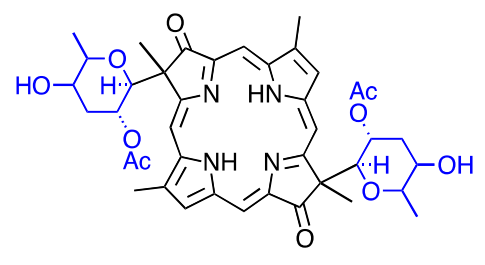

Tolyporphin A (10)

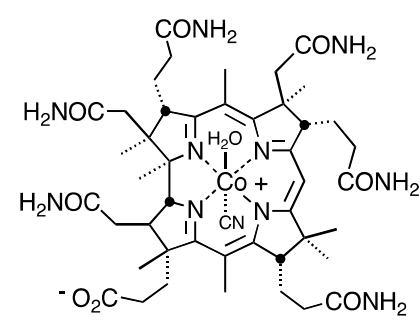

Cobyric Acid (11)

Most recently, Peter and his coworkers developed an efficient methodology for the synthesis of the furanosteroid class (12) of natural products, including wortmannin (13) and viridin (14). These materials are of interest because of their ability to selectively block certain intracellular signaling pathways, in particular those associated with cell growth and development. Accordingly, they have potential as new therapeutic agents for diseases that are characterized by rapid cell proliferation, including cancer. 


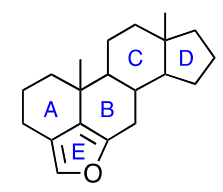

Furanosteroid (12)



Wortmannin (13)

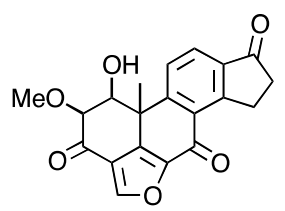

Viridin (14)

Peter's manifold contributions to natural products and heterocyclic chemistry are clearly apparent from the partial listing of outstanding publications that follow. The undergraduate and graduate students and postdoctoral associates he has supervised, mentored and taught have each benefited from his knowledge, insights, patience, and understanding as well as his deep personal interest in their success. His friends and colleagues have had the opportunity to share his humor, to enjoy his comradery, and to treasure his loyalty. I trust they will join me in wishing him cheers and all best wishes for the future.

Stephen F. Martin

Department of Chemistry

The University of Texas at Austin

Austin, TX 78712

\section{Selected Publications}

1. Jacobi, P. A.; Craig, T. J. Am. Chem. Soc. 1978, 100, 7748.

https://doi.org/10.1021/ja00492a063

2. Jacobi, P. A.; Ueng, S. N.; Carr, D. J. Org. Chem. 1979, 44, 2042.

https://doi.org/10.1021/jo01326a039

3. Jacobi, P. A.; Walker, D. G.; Odeh, I. M. A. J. Org. Chem. 1981, 46, 2065.

https://doi.org/10.1021/j000323a017

4. Jacobi, P. A.; Walker J. Am. Chem. Soc. 1981, 103, 4611.

https://doi.org/10.1021/ja00405a067

5. Jacobi, P. A.; Martinelli, M. J.; Taylor, E. C. J. Org. Chem. 1981, 46, 5416.

https://doi.org/10.1021/jo00339a037

6. Jacobi, P. A.; Craig, T. A.; Walker, D. G.; Arrick, B. A.; Frechette, R. F. J. Am. Chem. Soc. 1984, $106,5585$. https://doi.org/10.1021/ja00331a031

7. Jacobi, P. A.; Martinelli, M. J.; Polanc, S. J. Am. Chem. Soc. 1984, 106, 5594.

https://doi.org/10.1021/ja00331a032

8. Jacobi, P. A.; Selnick, H. J. Am. Chem. Soc. 1984, 106, 3041.

https://doi.org/10.1021/ja00322a054

9. Jacobi, P. A.; Kaczmarek, C. S. R.; Udodong, U. E. Tetrahedron Lett. 1984, 40, 4859.

https://doi.org/10.1016/S0040-4039(01)91243-2

10. Jacobi, P. A.; Frechette, R. F. Tetrahedron Lett. 1987, 43, 2937.

https://doi.org/10.1016/S0040-4039(00)96248-8

11. Jacobi, P. A.; Kaczmarek, C. S. R.; Udodong, U. E. Tetrahedron 1987, 43, 5475.

https://doi.org/10.1016/S0040-4020(01)87731-0

12. Jacobi, P. A.; Armacost, L. M.; Kravitz, J. I.; Martinelli, M. J.; Selnick, H. G. Tetrahedron Lett. 1988, $29,6865$. https://doi.org/10.1016/S0040-4039(00)88461-0 
13. Jacobi, P. A.; Armacost, L. M.; Kravitz J. I.; Martinelli, M. J. Tetrahedron Lett. 1988, $29,6869$. https://doi.org/10.1016/S0040-4039(00)88462-2

14. Jacobi P. A.; Kravitz, J. I. Tetrahedron Lett. 1988, 29, 6873. https://doi.org/10.1016/S0040-4039(00)88463-4

15. Jacobi P. A.; Buddhu, S.Tetrahedron Lett. 1988, 29, 4823. https://doi.org/10.1016/S0040-4039(00)80618-8

16. "The Total Synthesis of Saxitoxin," in Strategies and Tactics in Organic Synthesis, Volume II, Thomas Lindberg, Ed., Academic Press, Inc., New York, New York, 1989.

17. Jacobi, P.A.; Blum, C.; DeSimone R.; Udodong, U. Tetrahedron Lett. 1989, 30, 7173. https://doi.org/10.1016/S0040-4039(01)93926-7

18. Jacobi P. A.; Selnick, H. J. Org. Chem. 1990, 55, 202. https://doi.org/10.1021/jo00288a034

19. Jacobi P. A.; Zheng, W. Tetrahedron Lett. 1991, 32, 1279. https://doi.org/10.1016/S0040-4039(00)79645-6

20. Jacobi, P. A.; Blum, C. A.; DeSimone R. W.; Udodong, U. E. S. J. Am. Chem. Soc. 1991, 113, 5384. https://doi.org/10.1021/ja00014a033

21. Jacobi P. A.; Cann, R.O.; Skibbie, D. F. Tetrahedron Lett. 1992, 33, 2265. https://doi.org/10.1016/S0040-4039(00)74185-2

22. "Bis-Heteroannulation: Total Synthesis of Furanoterpenes, Butenolides, Lactones and Related Materials," in Advances in Heterocyclic Natural Product Synthesis, Volume II, William H. Pearson, Ed., Jai Press Inc., Greenwich, Connecticut, 1992.

23. Jacobi P. A.; Zheng, W. Tetrahedron Lett. 1993, 34, 2585.

https://doi.org/10.1016/S0040-4039(00)77631-3

24. Jacobi, P. A. Kravitz J.I. and Zheng, W.J. Org. Chem. 1995, 60, 376.

https://doi.org/10.1021/j000107a017

25. Jacobi, P. A.; Murphree, S.; Rupprecht, F.; Zheng, W. J. Org. Chem. 1996, 61, 2413.

https://doi.org/10.1021/j0952092u

26. Jacobi, P. A., Herradura, P. Tetrahedron Lett. 1997, 38, 6621.

https://doi.org/10.1016/S0040-4039(97)01533-5

27. Jacobi, P. A.; Lee, K., J. Am. Chem. Soc. 2000, 122, 4295.

ttps://doi.org/10.1021/ja994214w

28. Jacobi, P. A.; Pippin, D. Organic Letters 2001, 3, 827.

https://doi.org/10.1021/ol006977q

29. Jacobi, P. A.; Herradura, P. J. Can. Chem. Soc. 2001, 1727.

https://doi.org/10.1139/cjc-79-11-1727

30. Jacobi, P. A.; Li, Y. J. Am. Chem. Soc. 2001, 123, 9307.

https://doi.org/10.1021/ja016303q

31. Jacobi, P. A.; Odeh, I. M. A.; Buddhu, S. C.; Cai, G.; Rajeswari, S.; Fry, D.; Zheng, W.; DeSimone, R. D. W.; Guo, J.; Coutts, L. D.; Hauck, S. I.; Leung, S. H.; Ghosh, I.; Pippin, D. Synlett 2005, 19 2861-2885.

https://doi.org/10.1055/s-2005-918956

32. Sessions, E. H.; Jacobi, P. A. Organic Letters 2006, 8, 4125.

https://doi.org/10.1021/ol061697h

33. Sessions, E. H.; O'Connor, R. T.; Jacobi, P. A. Org. Lett. 2007, 9, 3221.

https://doi.org/10.1021/ol061697h 
34. O'Neal, W.; Jacobi, P. A. J. Am. Chem. Soc. 2008, 130, 1102.

https://doi.org/10.1021/ja0780075

35. Wang, H.; Tassa, C.; Jacobi, P. A. Org. Lett. 2008, 10, 2837.

https://doi.org/10.1021/ol800985m

36. Wang, H.; Jacobi, P. A. Arkivoc 2010, 15.

https://doi.org/10.3998/ark.5550190.0011.403

37. Jacobi, P. A.; Brielmann, H. L.; Chiu, M.; Ghosh, I.; Hauck, S. I.; Lanz, S.; Leung, S.; Li, Y.; Liu, H.; Löwer, F.; O'Neal, W. G.; Pippin, D.; Pollina, E.; Pratt, B. A.; Robert, F.; Roberts, W. P.; Tassa, C.; Wang., H. Heterocycles 2011, 82, 1029-1081.

https://doi.org/10.3987/REV-10-SR(E)6

38. Onyango, E. O.; Jacobi, P. A. J. Org. Chem. 2012, 77, 7411-7427.

https://doi.org/10.1021/jo301232w

39. Jacobi, P. A.; Konekamp, T.; Mascall, K. C. M.; O'Connor, R. t.; Onyango, E. O.; Sessions, E. H. Advances in Heterocyclic Chemistry, 2013.

40. John Wiley \& Sons Ltd., Hoboken, New Jersey, USA, 2019. 